\title{
Ethyl Acetate Extract of Red Melinjo (Gnetum Gnemon L.) Peel as Antibacterial Compound
}

\author{
Adolf J. N. Parhusip ${ }^{1, *}$, Veliana Angel ${ }^{1}$, Nuri A. Anugrahati ${ }^{1}$, \\ Johan Honga ${ }^{1}$, Wenny S. L. Sinaga ${ }^{1}$ \\ ${ }^{I}$ Food Technology Department, University of Pelita Harapan, Tangerang, Indonesia \\ "Corresponding author. Email: adolf.parhusip@uph.edu
}

\begin{abstract}
Melinjo (Gnetum gnemon L.) is a native plant in Indonesia. Melinjo peel is generally disposed of, although it contains tannin, flavonoid and saponin, which can be used as antimicrobial compounds. The purpose of this research was to analyze the antimicrobial activity of melinjo peel extract. Maceration method was conducted to extract the melinjo peel, using ethyl acetate as the solvent. The extract at concentration of $4,8,12$, and 16\% (w/v) could inhibit Escherichia coli ATCC 8739, Bacillus cereus ATCC 10876, and Pseudomonas aeruginosa ATCC 9027, but could not inhibit Rhizopus oligosporus ATCC 22959. The extract MIC and MBC value was ranged from $0.50-0.69 \%$ and $2.00-2.76 \%$, respectively. Alkaloids, saponin, phenolic, flavonoids and glycosides were found in the extract. The inhibition of selected extract (12\%) had a similar level to $1000 \mathrm{ppm}$ Colistin against $\underline{\mathrm{E}}$. coli and $\underline{\mathrm{P}}$. aeruginosa. Low $\mathrm{pH}(\mathrm{pH} 4)$ increased the inhibition of the extract, while neutral $\mathrm{pH}$ decreased the inhibition. Heating extract at $65{ }^{0} \mathrm{C}$ for 30 minutes increased the inhibition, whereas heating at 75,85 , and $95{ }^{\circ} \mathrm{C}$ decreased the inhibition. The present of salt and sugar at concentration of $1-5 \%$ and $10-50 \%$, respectively, increased the inhibition. The extract could damage cell morphology and was confirmed by the presence of ions $\left(\mathrm{Ca}^{2+}, \mathrm{K}^{+}\right.$, dan $\left.\mathrm{Mg}^{2+}\right)$ outside of the cells.
\end{abstract}

Keywords : melinjo, extract, antimicrobial, cell damage

\section{INTRODUCTION}

Melinjo (Gnetum gnemon L.) is one of the native plants in Southeast Asia and Western Pacific Ocean from Assam, through Indonesia, Malaysia, Philippines and Fiji [1]. The production of melinjo has increased from 197.648 tons in 2014 to 213.025 tons in 2015 [2].

Melinjo peel is sometimes consumed as vegetables but is often discarded [3]. Melinjo peel contains bioactive compound such as tannin, flavonoid and saponin [4]. These compounds serve as medicine, antibody, an antimicrobial compound, pigment, and anti-inflammation [3]. Therefore, further utilization of melinjo peel is needed as an antimicrobial compound.

Antimicrobial substances are biological or chemical compounds that can inhibit microbial growth and activity [5]. Reference [3] study showed that melinjo peel with concentration of $15 \%$ using ethyl acetate solvents could inhibit $P$. aeruginosa bacteria as much as $6.73 \mathrm{~mm}$, greater than Penicillin $G$ antibiotics that were not able to inhibit P. aeruginosa.

In this study red melinjo peel was used. This is based on the results of another research, which showed that red melinjo peel contains a higher total phenolic content
(0.386 mg GAE/g sample) than yellow (0.103 mg GAE/ $\mathrm{g}$ sample) and green Melino peel (0.095 mg GAE/ g sample) [6]. Phenolic is an antibacterial compound due to the presence of reactive hydroxyl group [7]. Melinjo peel extraction was carried out by the maceration method using ethyl acetate solvents. Maceration is an extraction method without heating and carried out at room temperature, so it can prevent damage to the phytochemical compound [8]. The results showed that ingredients extracted by ethyl acetate contains higher flavonoid content than the ingredients extracted with ethanol [9]. Reference [3] study showed that ethyl acetate extract of melinjo peel at a concentration of $15 \%$ was able to inhibit $P$. aeruginosa bacteria with a diameter of $6.64 \mathrm{~mm}$, greater than ethanol extract of melinjo peel which could not inhibit $P$. aeruginosa at all at the same concentration.

The antimicrobial assay was carried out using four types of microbes, namely E. coli, B. cereus, $P$. aeruginosa and $R$. oligosporus. These microbes are pathogenic microbes that are commonly found in the environment. Each microbe represents Gram-negative bacteria, spore forming Grampositive bacteria, and molds, so the antimicrobial assay can be determined by its effectivity based on the type of microbes.

Ethyl acetate extract of red melinjo peel would be analyzed for the antimicrobial activity against four types of 
microbes at different concentrations, then the selected concentration of extracts would be determined. Selected extract would then be analyzed further for the phytochemical component qualitatively, compared with antibiotic compounds, and the stability of selected extracts will be tested against $\mathrm{pH}$, heating temperature, salt and sugar concentration. In addition, the selected ethyl acetate extract of red melinjo peel would be tested for its effect on ion leakage and microbial morphology by Atomic Absorption Spectroscopy (AAS) and Scanning Electron Microscope (SEM) methods.

\section{METHODS}

The research was conducted in the University of Pelita Harapan, between August-December 2019. This research used IBM Statistical Package for the Social Sciences (SPSS) ver. 22, application to analyze the data. The design of the experiment was using a completely randomized design with one and two factors. Completely randomized design with two factors was used to analyze the comparison of extract with Colistin antibiotics, the extract stability against $\mathrm{pH}$, heating temperature, salt and sugar concentration. Meanwhile, completely randomized design with two factors was used to compare extract with Penicillin $\mathrm{G}$ antibiotics.

\section{a. Materials and Equipment}

Materials used for this research were red melinjo peel obtained from Bogor, ethyl acetate, demineralized water, crystal violet, lugol, 96\% alcohol, safranin, immersion oil, Nutrient Agar (NA) medium, Nutrient Broth (NB) medium, B. cereus ATCC 10876 from Institut Pertanian Bogor (IPB), E. coli ATCC 8739 from IPB, P. aeruginosa ATCC 9027 from IPB, R. oligosporus ATCC 22959 from IPB, magnesium ribbon, amyl alcohol, $5 \%$ and $1 \%$ iron (III) chloride $\left(\mathrm{FeCl}_{3}\right)$, chloroform, ammonia, concentrated sulfuric acid $\left(\mathrm{H}_{2} \mathrm{SO}_{4}\right), 4 \mathrm{~N} \mathrm{H}_{2} \mathrm{SO}_{4}$, Dragendorff reagent reaction, Meyer reagent reaction, Wagner reagent reaction, acetic acid anhydrous, ethanol, eter, Whatman filter paper no. 1, concentrated chloric acid $(\mathrm{HCl}), 1 \mathrm{M}$ and $2 \mathrm{~N} \mathrm{HCl}$, $0,5 \mathrm{M}$ potassium hydroxide $(\mathrm{KOH}), 5 \%$ hydrogen peroxide, benzene, $\mathrm{KH}_{2} \mathrm{PO}_{4}$, sodium chloride solution, sugar solution, and alumunium foil.

Equipment used for this research were cabinet dryer, autoclave, ose needle, glass slide, bunsen burner, pipette, microscope, hairdryer, petri dish, incubator, micropipette, test tube, threaded test tube, vortex, water bath, heater, magnetic stirrer, rotary evaporator, evaporating dish, bulb pump, Mohr pipette, $\mathrm{pH}$ meter, oven, analytical balance, $10 \mathrm{~mL}$ volumetric flask, stirring rod, separating funnel, Erlenmeyer flask, centrifuge, SEM, and AAS.

\section{b. Powder Making and Extraction of Red Melinjo Peel}

Red melinjo was washed and peeled, seed was disposed, and the peel was dried using a cabinet dryer at $50^{\circ} \mathrm{C}$ for 24 hours. Dry red melinjo peel was crushed using a dry blender, then sifted using an abrasive screener (Ø: 35 Mesh) to obtain powdered red melinjo peel. Red melinjo peel powder was extracted using ethyl acetate with a ratio between melinjo peel to solvent of 1:4. The extraction was carried out using a shaker at $110 \mathrm{rpm}$. The mixture was then filtered with Whatman filter paper no. 1 so that the filtrate and dregs is obtained. Dregs were disposed, while the filtrate was evaporated using a rotary evaporator at $55^{\circ} \mathrm{C}$, then blasted with nitrogen gas to obtain ethyl acetate extract of red melinjo peel [10] (with modification).

\section{c. Antimicrobial Assay}

This test was carried out using well diffusion method with modification. Ethyl acetate extract of red melinjo peel of 0 , $4,8,12$, and $16 \%(\mathrm{w} / \mathrm{v})$ concentrations were each put into a well with a diameter of $6 \mathrm{~mm}$ as much as $60 \mu \mathrm{L}$ on NA media containing the test microorganisms. The petri dish was incubated at $37^{\circ} \mathrm{C}$ for 24 hours, and the inhibition zone diameter was measured [11] [12].

\section{d. Qualitative Determination of Phytochemical Compound}

Qualitative determination of phytochemical compound included flavonoids [13], phenolic [14], alkaloids [15], steroids and triterpenoids [15], terpenoids [16], tannins [15], saponin [15] [17], and glycosides [18].

\section{e. Antibiotics Testing Comparison}

This test was carried out using well diffusion method [12]. The antibiotics used were Penicillin G and Colistin. The antibiotics with concentrations of 10,100 , and 1000 ppm were put into a well with a diameter of $6 \mathrm{~mm}$ as much as $60 \mu \mathrm{L}$ on NA. The petri dish was incubated at $37^{\circ} \mathrm{C}$ for 24 hours, then the inhibition zone diameter was measured.

\section{f. Stability Test of Selected Extract against $\mathrm{pH}$, Heating Temperature, Salt and Sugar Concentration}

The stability test of selected extracts at various $\mathrm{pH}$ was carried out by mixing selected extracts with solutions at $\mathrm{pH} 4,5,6$, and 7, then antimicrobial activity was tested by a well diffusion method [19].

The stability test of the selected extract at various heating temperatures was carried out by heating the extract at 65 , 75,85 , and $95^{\circ} \mathrm{C}$ for 30 minutes using a water bath. Then the extract was tested for its antimicrobial activity by the well diffusion method [20] (with modification).

Stability testing of selected extracts at various salt concentrations was carried out by mixing selected extracts into sterile salt solutions with concentrations of 1, 2, 3, 4, and $5 \%$, Testing of antimicrobial activity carried out by well diffusion method [19].

The stability test of the selected extract at various sugar concentrations was carried out by dissolving the selected extract into sugar solutions with concentrations of 10, 20, 30,40 , and $50 \%$. Antimicrobial activity was tested by the well diffusion method [20]. 


\section{g. Atomic Absorption Spectroscopy (AAS)}

The AAS test aimed to determine bacterial cell leakage, which focuses on the amount of calcium ions $\left(\mathrm{Ca}^{2+}\right)$, potassium $\left(\mathrm{K}^{+}\right)$, and magnesium $\left(\mathrm{Mg}^{2+}\right)$. The bacterial culture was rejuvenated with Nutrient Broth (NB) media for 24 hours. Then, ethyl acetate extract of red melinjo peel was added to the bacterial culture as much as $12 \%$, then incubated at $37^{\circ} \mathrm{C}$ for 24 hours. Samples were sent to Pusat Penelitian Ilmu Pengetahuan dan Teknologi (Puspiptek) to analyze $\mathrm{Ca}^{2+}, \mathrm{K}^{+}$, and $\mathrm{Mg}^{2+}$ ions. The number of $\mathrm{Ca}^{2+}$ ions was analyzed by AAS at a wavelength of $422.7 \mathrm{~nm}, \mathrm{~K}^{+}$ions at a wavelength of 766.5 $\mathrm{nm}$, and $\mathrm{Mg}^{2+}$ ions at a wavelength of $285.2 \mathrm{~nm}$ [3] (with modification).

\section{h. Scanning Electron Microscope (SEM)}

The SEM method was used to determine the morphological changes of bacteria that had been treated with the selected ethyl acetate extract of red melinjo peel. A bacterial culture that had been refreshed in NB media at $37^{\circ} \mathrm{C}$ for 24 hours, were added with $12 \%$ concentration of ethyl acetate extract of red melinjo peel. The mixture was homogenized with a vortex, then incubated at $37^{\circ} \mathrm{C}$ for 24 hours. Then the sample was put into a centrifuge at a speed of $15,000 \mathrm{rpm}$ for 7 minutes so that the precipitate and filtrate were obtained. The filtrate was discarded, while the precipitate was sent to Institut Teknologi Bandung for analysis. The precipitate was applied to a carbon-coated plate. Then, the plate was coated with aurum under vacuum condition, and the sample was ready to be inserted into the SEM instrument [3] (with modification).

\section{RESULTS AND DISCUSSION}

\section{a. Ethyl Acetate Extract of Red Melinjo Peel}

Red melinjo that was used in this research was Gnetum gnemon L., Gnetaceae genus, from Bogor. The percentage of peel on red melinjo fruit was $36.10 \%$. Fresh red melinjo peel with moisture content $73.30 \%$ decreased to $5.58 \%$ after drying process. The yield of red melinjo peel powder was $89.24 \%$, with moisture content of $9.87 \%$. The yield of extract produced was $1.41 \%$.

\section{b. Antimicrobial Assay}

Antimicrobial assay of ethyl acetate extract of red melinjo peel was conducted using well diffusion method with 0,4 , 8,12 , and $16 \%$ concentrations. According to Figure 1, it can be seen that ethyl acetate extract of red melinjo peel could inhibit $E$. coli, B. cereus, and $P$. aeruginosa bacteria, while it could not inhibit $R$. oligosporus mould. The extract could not inhibit $R$. oligosporus due to the presence of ergosterol, a sterol that is only found in the fungal membrane. The interaction between essential oil and ergosterol will cause damage to the cell membrane, causing leakage of fungal cell [21]. There is a possibility that red melinjo peel does not contain essential oil.

Gram-negative bacteria (E. coli and P. aeruginosa) had a lower inhibition zone diameter than Gram-positive bacteria
(B. cereus). Gram-negative bacteria consists of two membranes (inner and outer membrane) that sandwich a layer of peptidoglycan. Meanwhile, Gram-positive bacteria has a thicker layer of peptidoglycan that surrounds a single cytoplasmic membrane. The inner membrane of Gramnegative bacteria is as same as cytoplasmic membrane of Gram-positive bacteria that contains phospholipids and proteins. The outer membrane of Gram-negative bacteria contains lipoproteins and glycolipids (in the outer leaflet consists lipopolysaccharides) which are not present in the cytoplasmic membrane [22]. The presence of outer membrane could inhibit the antimicrobial compounds to diffuse inside bacterial peptidoglycan membrane and cell [3].

Figure 2 shows that the increase of extract concentration would increase the inhibition zone diameter. This was due to the higher content of antimicrobial compounds in the extract, therefore increasing the inhibition zone. The inhibition zone diameter of more than $20 \mathrm{~mm}$ is classified as very strong, the inhibition zone diameter of $10-20 \mathrm{~mm}$ is classified as strong, the inhibition zone diameter of 5-10 $\mathrm{mm}$ is classified as moderate and the inhibition zone diameter of $5 \mathrm{~mm}$ or less is classified as weak [23]. The ethyl acetate extract of red melinjo peel could be classified as strong. Due to efficiency, the selected extract of ethyl acetate of red melinjo peel was at $12 \%$ concentration.

\section{c. $M I C, M B C$, and $M F C$ Value of The Extract}

Table 1 shows the MIC, MBC, and MFC value of ethyl acetate extract of red melinjo peel against the test microbes (mikroba uji). The inhibition of the extract was more effective against Gram-positive bacteria ( $B$. cereus) than Gram-negative bacteria (E. coli and $P$. aeruginosa). This was due to the presence of the outer membrane of Gramnegative bacteria [22] that inhibits the antimicrobial compounds to diffuse inside bacterial peptidoglycan membrane and cell [3]. According to the results of reference [4], the MIC and MBC value of ethanol extract of melinjo peel was 1.40 and $5.58 \%$ respectively, greater than ethyl acetate extract of red melinjo peel. Moreover, the ethyl acetate extract of red melinjo peel against $P$. aeruginosa bacteria has the MIC and MBC values of 1.36 and $5.43 \%$ respectively which is greater than the value in this study.

Table 1. MIC, MBC, and MFC Values of Ethyl Acetate Extract of Red Melinjo Peel Against 4 Types of Microbes

\begin{tabular}{|l|c|c|c|}
\hline Microbes & MIC (\%) & $\begin{array}{c}\text { MBC } \\
\mathbf{( \% )}\end{array}$ & $\begin{array}{c}\text { MFC } \\
\mathbf{( \% )}\end{array}$ \\
\hline E. coli & 0.69 & 2.76 & - \\
\hline B. cereus & 0.50 & 2.00 & - \\
\hline P. aeruginosa & 0.67 & 2.68 & - \\
\hline R. oligosporus & - & - & 0 \\
\hline
\end{tabular}

The differences between the MIC and MBC value can be caused by environmental factors. Phenolic compounds will be produced by plants in response to environmental stress [24]. The mineral content in the soil (such as aluminum, potassium, sulfur, sodium, and manganese), 
and climate also affected the plant phenolic content [25]. The higher content of antimicrobial compounds in plants will decrease the value of MIC and MBC. The lower value of MIC and MBC shows that the component has a strong inhibition activity.

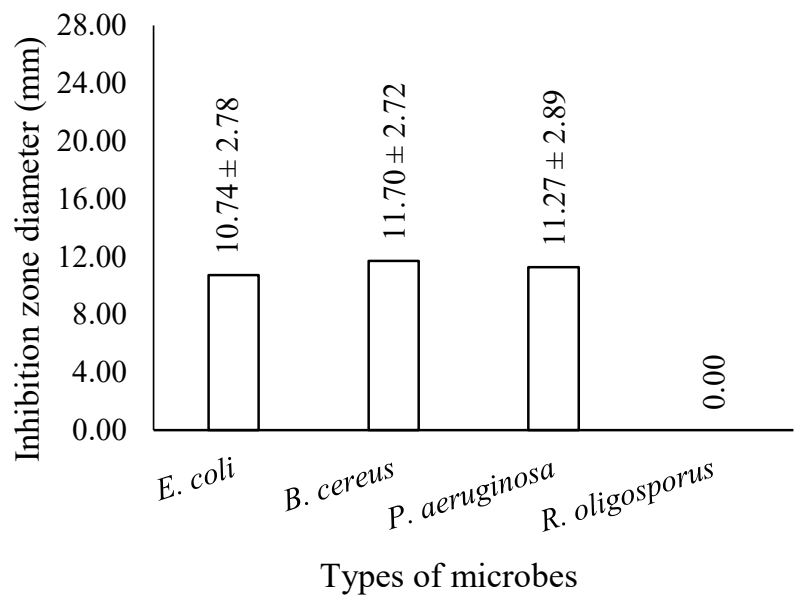

Figure 1. Inhibition Zone Diameter of Ethyl Acetate Extract of Red Melinjo Peel against 4 Types of Microbes

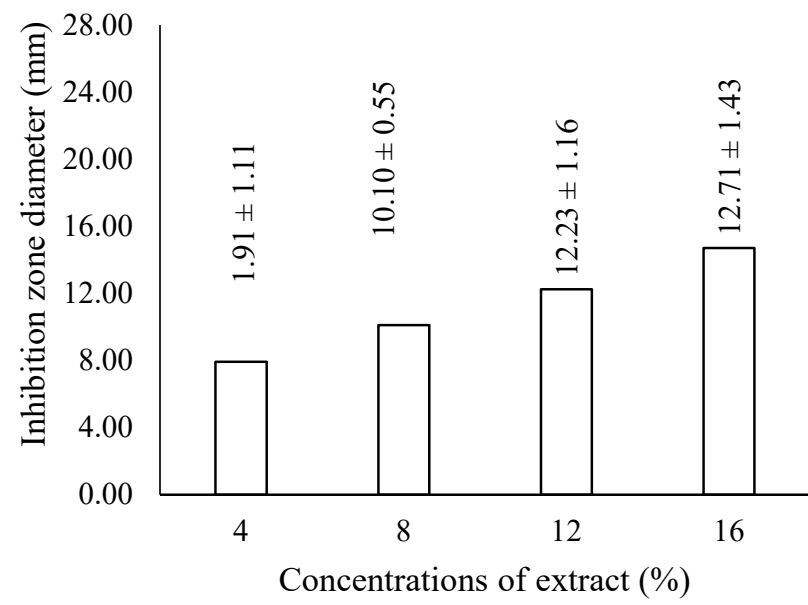

Figure 2. Average Inhibition Zone Diameter of Ethyl Acetate Extract of Red Melinjo Peel at Various Concentrations

\section{d. Qualitative Analysis of Phytochemical Compound in Extract}

The results of the qualitative analysis of phytochemical compound in the extract can be seen in Table 2. The analysis showed positive results for alkaloids, saponin, phenolics, flavonoids, and glycosides. The presence of these compounds showed that ethyl acetate could extract the compounds based on the polarity. Ethyl acetate is a semi-polar solvent that can extract alkaloids, aglycone, glycosides, sterols, terpenoids, and flavonoids [26].

\section{e. Comparison of Selected Extract and Antibiotics}

The results of ANOVA statistical analysis showed that there was significant differences $(p<0.05)$ between 1000 ppm Colistin anitibiotics inhibition zones diameter with selected ethyl acetate extract of red melinjo peel (12\%). Figure 3 shows the inhibition zone diameter of selected ethyl acetate extract of red melinjo peel compared to Colistin antibiotics against $E$. coli and $P$. aeruginosa bacteria. Ethyl acetate extract of red melinjo peel has an inhibition zone diameter 1.44 times greater than $1000 \mathrm{ppm}$ Colistin against $E$. coli, and 1.50 times greater against $P$. aeruginosa. Overall, the inhibition zone diameter of ethyl acetate extract of red melinjo peel was 1.47 times greater than 1000 ppm Colistin.

Colistin or Polymyxin E is amphiphatic (has polar and nonpolar parts), and interacts like detergent against cell membranes, which can disrupt the structure of the cell membranes. The bond between a cationic polypeptide (Colistin) and anionic lipopolysaccharide (the outer membrane of Gram-negative bacterial cell) causes disruption of the bacterial cell membrane. Colistin replaces magnesium and calcium ions (ions that serve as lipopolysaccharide molecules stabilizer) in anionic lipopolysaccharides, resulting in an unstable cell membrane structure, increased cell permeability, leakage of cell contents, and cell death [27].

The results of ANOVA statistical analysis showed that there was a significant difference $(p<0.05)$ between 1000 ppm Penicillin $\mathrm{G}$ antibiotics inhibition zone diameter and selected ethyl acetate extract of red melinjo peel (12\%). Based on Figure 4, ethyl acetate extract of red melinjo peel has inhibition diameter 0.74 times smaller than $100 \mathrm{ppm}$ Penicillin $G$ antibiotics. Penicillin $G$ works as transpeptidase enzyme inhibitor, one of the Penicillin binding proteins (PBPs), that builds bacterial cell wall [28]. Penicillin is a structural analog in the form of Dalanyl-D-alanyl, so it may bind with transpeptidase (acylD-alanyl-D-alanyl structure) that catalyzes the crosslinking reaction.

\section{f. Stability of Selected Extract against $\mathrm{pH}$}

The results of ANOVA statistical analysis showed that $\mathrm{pH}$ has a significant effect $(\mathrm{p}<0.05)$ on the inhibition zone diameter. Based on Figure 5, it can be seen that at $\mathrm{pH} 4$ the selected ethyl acetate extract of red melinjo peel has a greater inhibition zone diameter than $\mathrm{pH}$ 7. This showed that the lower the $\mathrm{pH}$, the greater the inhibition zone diameter of ethyl acetate extract of red melinjo peel.

This study has similar results to another research, that ethyl acetate extract of akway bark has a greater inhibition zone diameter at $\mathrm{pH} 4$ than $\mathrm{pH} 7$ [29]. In acid condition, the $\mathrm{pH}$ of cell cytoplasm will decrease, causing disruption of enzyme activity inside the cell [30]. Acid can cause damage of the outer cell membrane and lead to penetration of hydrophobic antibacterial compound inside cell [31]. 
Table 2. The Results for Qualitative Analysis of Phytochemical Compound in Ethyl Acetate Extract of Red Melinjo Peel

\begin{tabular}{|l|c|}
\hline Phytochemicals analysis & Results \\
\hline Alkaloids & + \\
\hline Saponin & + \\
\hline Tannin & - \\
\hline Phenolics & + \\
\hline Flavonoids & + \\
\hline Triterpenoids & - \\
\hline Steroids & - \\
\hline Glycosides & + \\
\hline
\end{tabular}

Note: $(+)$ : positive, (-) : negative

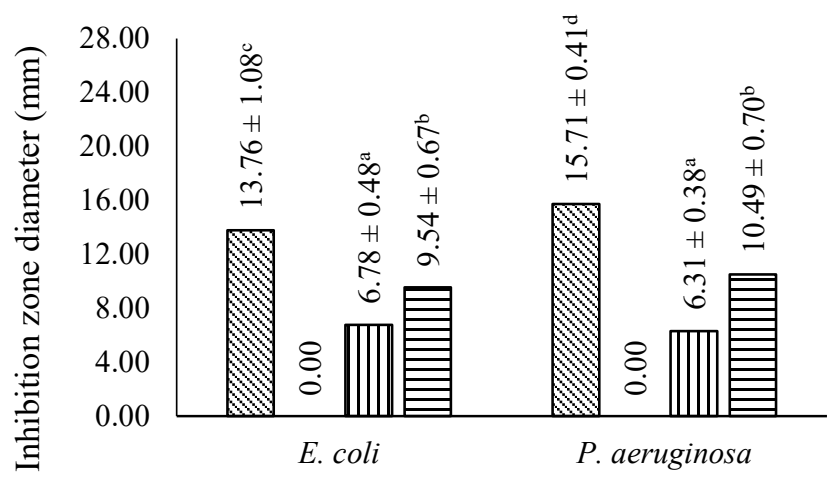

Ethyl acetate extract of red melinjo peel (12\%)

10 ppm colistin

\ 100 ppm colistin

曰 $1000 \mathrm{ppm}$ colistin

Note: a.b.c.d same superscripts indicate there is no significant difference at $\alpha=5 \%$

Figure 3. Inhibition Zone Diameter of Ethyl Acetate Extract of Red Melinjo Peel Compared with Colistin Antibiotics

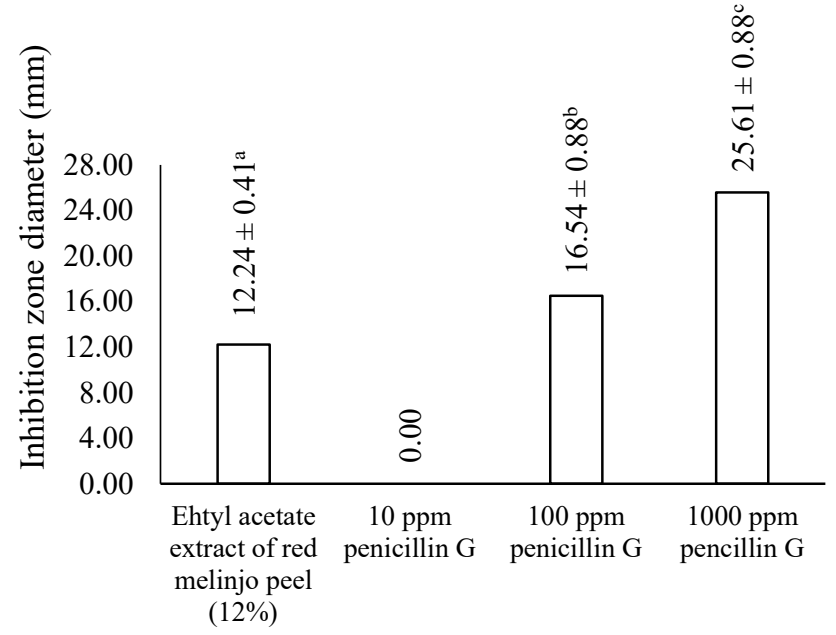

Note: ${ }^{\text {a.b.c }}$ same superscripts indicate there is no significant difference at $\alpha=5 \%$

Figure 4. Inhibition Zone Diameter of Ethyl Acetate Extract of Red Melinjo Peel Compared with Penicillin G Antibiotics

\section{g. Stability of Selected Extract against Heating Temperature}

The results of ANOVA statistical analysis showed an interaction between type of microbes and heating temperature significantly affect $(p<0.05)$ to the inhibition zone diameter. Figure 6 shows the inhibition zone diameter of the ethyl acetate extract of red melinjo peel at various heating temperatures. The extract that was heated at $65^{\circ} \mathrm{C}$ has the greatest inhibition zone diameter than the other treatments. This was caused by the activation of flavonoids that was heated up to $70^{\circ} \mathrm{C}$ [32]. This study has a similar result, which heating at 75,85 , and $95^{\circ} \mathrm{C}$ would lead to damage of the active compounds, causing the inhibition zone diameter to decrease [32].

Extract that was heated at $95^{\circ} \mathrm{C}$ has the lowest inhibition zone diameter, which shows that the antimicrobial compounds are damaged. This study has similar results to another research, that heated garlic extract at $100^{\circ} \mathrm{C}$ showed no inhibition zone diameter compared to the extract that was heated at $65^{\circ} \mathrm{C}$ [33]. The result of another research also showed that increasing heating temperature will damage the flavonoids compounds [34].

\section{h. Stability of Selected Extract against Salt Concentrations}

The results of ANOVA statistical analysis showed interaction between type of microbes and salt concentrations significantly affect $(\mathrm{p}<0.05)$ the inhibition zone diameter. Figure 7 shows the inhibition zone diameter of ethyl acetate extract of red melinjo peel at various salt concentrations against $E$. coli, B. cereus, and $P$. aeruginosa. Increasing salt concentrations will increase the inhibition zone diameter. Therefore, it can be stated that there is synergism between ethyl acetate extract of red melinjo peel and salt concentrations.

Salt has the bactericidal (killing) and bacteriostatic (inhibits) properties. Salt will inhibit microbes bacteriological and enzymatic activities. Sodium chloride salt can increase substrate's osmotic pressure, causing the water in the cell to come out, the cell shrinks, and inhibits microorganism activity. The ionization of sodium chloride will produce chlorine ions which are toxic to microorganisms, which also block the respiration system [35].

\section{i. Stability of Selected Extract against Sugar Concentrations}

The results of ANOVA statistical analysis showed that type of microbes has a significant effect $(p<0.05)$ on the inhibition zone diameter. The type of microbes (Grampositive and Gram-negative bacteria) will affect the inhibition zone diameter. Figure 8 shows the inhibition zone diameter of ethyl acetate extract of the red melinjo peel against $E$. coli, B. cereus, and $P$. aeruginosa. Gramnegative bacteria ( $E$. coli and $P$. aeruginosa) has the greater inhibition zone diameter than Gram-positive bacteria (B. cereus). This was due to the presence of the outer membrane of Gram-negative bacteria [22] that 
inhibits the antimicrobial compounds to diffuse inside bacterial peptidoglycan membrane and cell [3]. The presence of sugar bonds causing the flavonoids to be more soluble in water, so that the ethyl acetate fraction easily diffused and penetrate to $B$. cereus cell wall that contains protein (polar), phospholipids and lipoproteins (nonpolar) [36].

Figure 9 shows that the increase of sugar concentrations will increase the inhibition zone diameter of ethyl acetate extract of red melinjo peel. Reference [37] stated that $10 \%$ sugar solution can increase the osmotic pressure, causing the water inside of the cell to come out. The cell will lack of water and leading cell death by lysis.

Sucrose is a disaccharide that is used as a preservative [38]. Increasing sugar concentrations will increase the osmotic pressure outside of the cell, causing the water inside of the cell to come out, and leading to cell death by lysis [39]. If the osmotic pressure outside of the cell is higher than inside as the sugar addition, then the water inside of the cell will be pulled out, causing the cytoplasm membrane to detach form the cell wall (plasmolysis). As the water release inside of the cell causing the cell to shrink [38].

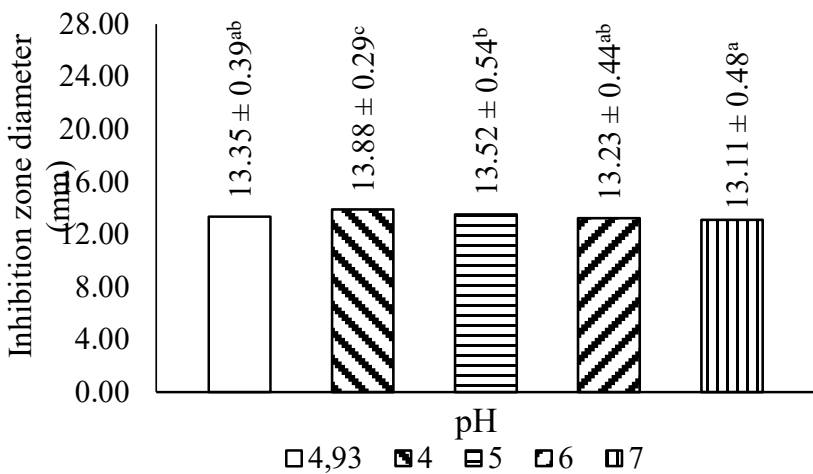

Note: ${ }^{\text {a.b.c }}$ same superscripts indicate there is no significant difference at $\alpha=5 \%$

Figure 5. Average Inhibition Zone Diameter of Selected Ethyl Acetate Extract of Red Melinjo Peel at Various $\mathrm{pH}$

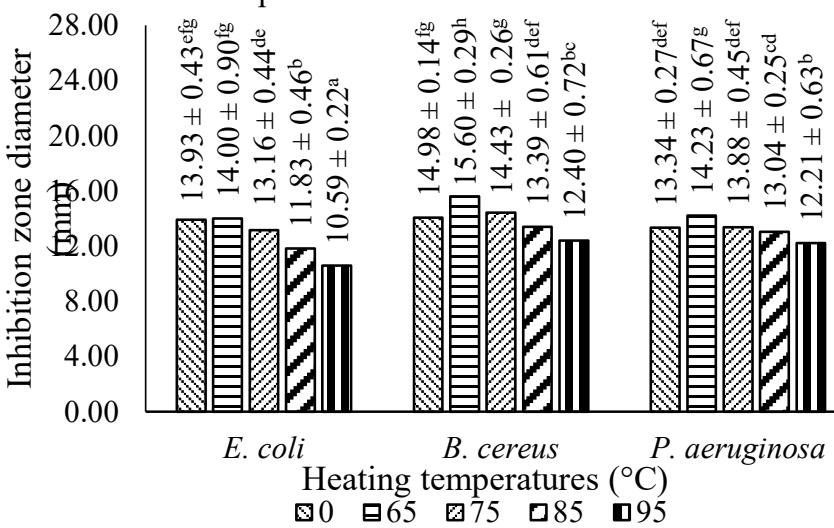

Note: a,b,c,d,e,f,g,h same superscripts indicate there is no significant difference at $\alpha=5 \%$

Figure 6. Inhibition Zone Diameter of Selected Ethyl Acetate Extract of Red Melinjo Peel at Various Heating Temperatures

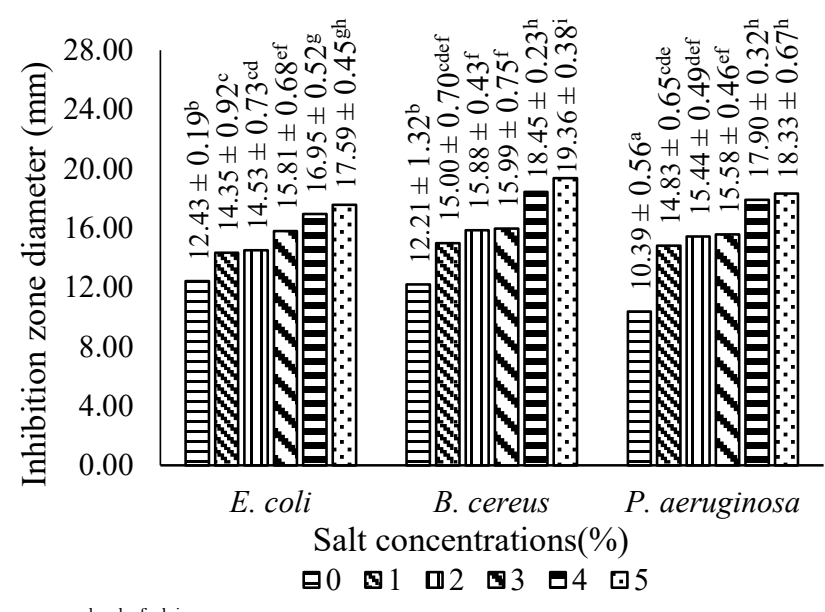

Note: a,b,c,d,e,f,g,h,i same superscripts indicate there is no significant difference at $\alpha=5 \%$

Figure 7. Inhibition Zone Diameter of Selected Ethyl Acetate Extract of Red Melinjo Peel at Various Salt Concentrations

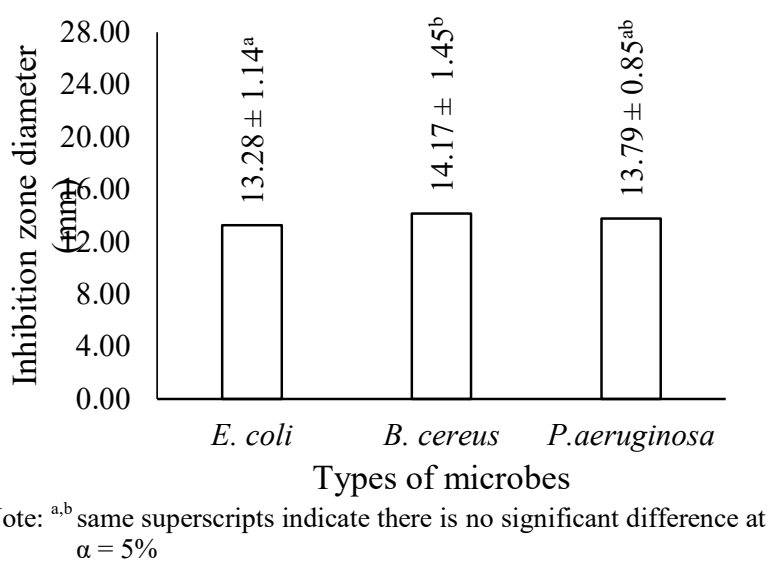

Figure 8. Average Inhibition Zone Diameter of Ethyl Acetate Extract of Red Melinjo Peel at Various Sugar Concentrations

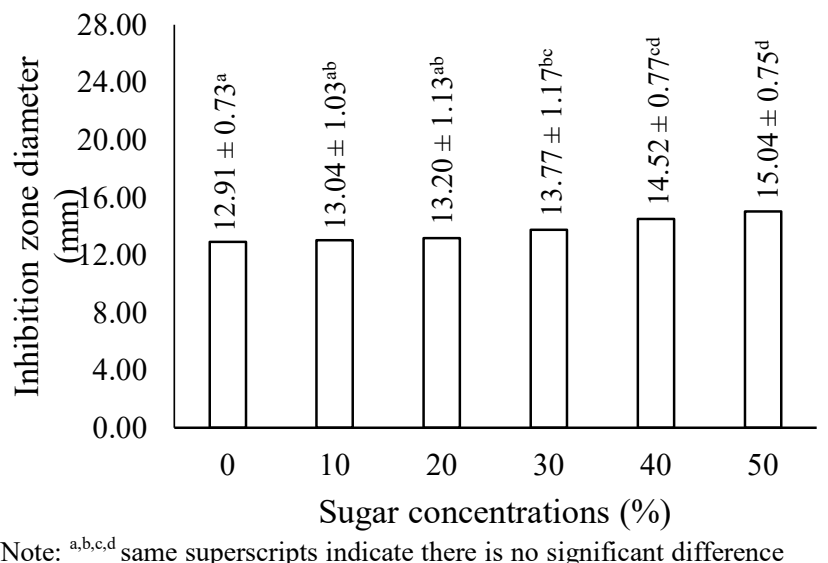

Note: ${ }^{a, b, c, d}$ same superscripts indicate there is no significant difference at $\alpha=5 \%$

Figure 9. Average Inhibition Zone Diameter of Ethyl Acetate Extract of Red Melinjo Peel at various Sugar Concentrations against E. coli, B. cereus, and $P$. aeruginosa 


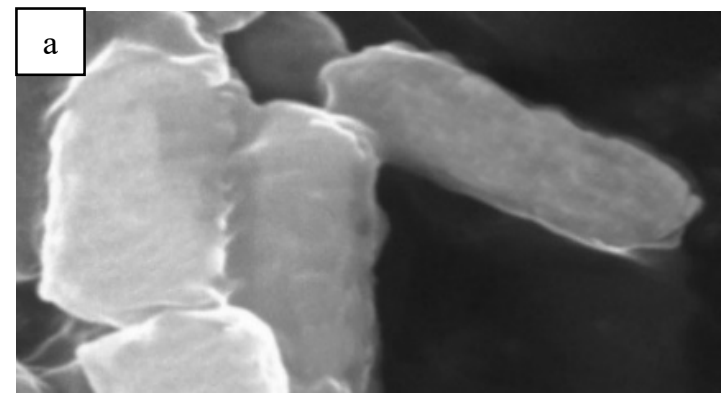

Magnification : 40.000x

Shape : rod

Condition : normal (soft surface)

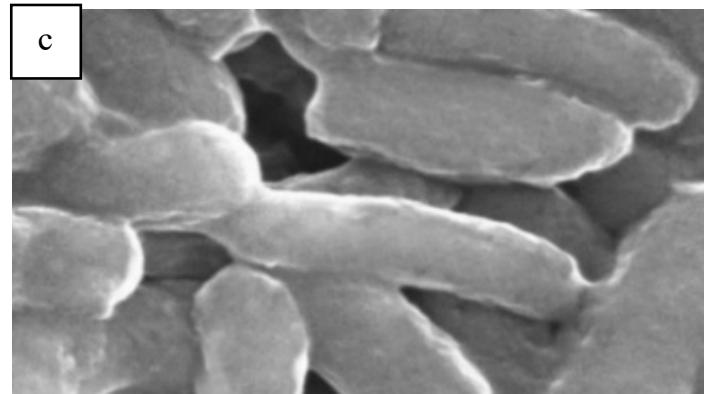

Magnification : 40.000x

Shape : :rod

Condition : normal (soft surface)

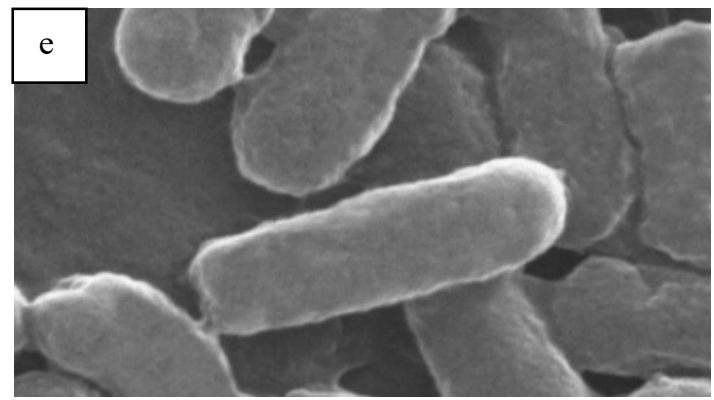

Magnification : 40.000x

Shape : rod

Condition : normal (soft surface)

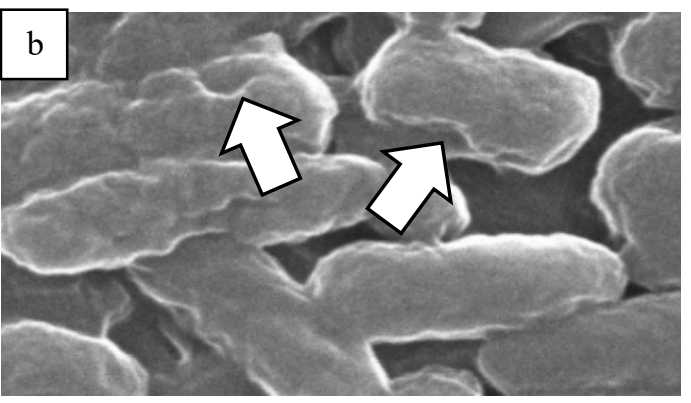

Magnification : 40.000x

Shape : rod

Condition : shrunken and swollen

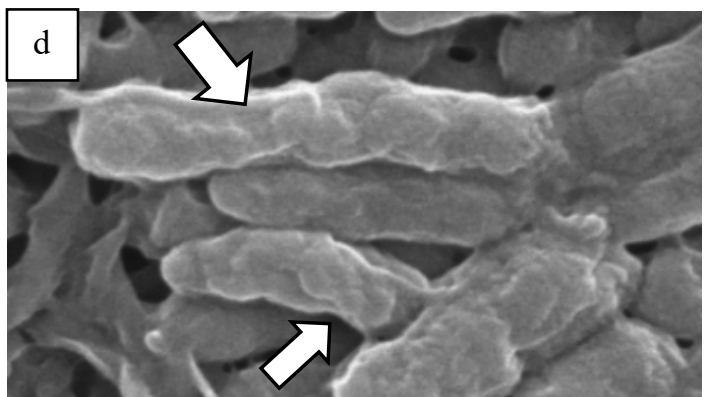

Magnification : 40.000x

Shape : :rod

Condition : shrunken, swollen, and elongated

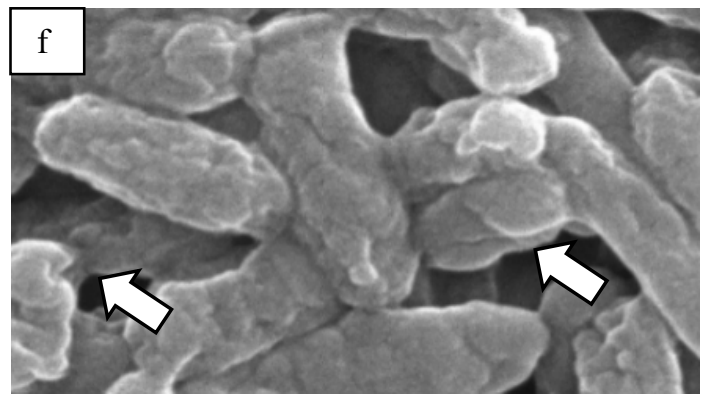

Magnification : 40.000x

Shape : rod

Condition : shrunken and swollen

Note:

E. coli bacteria before (a) and after (b) contacted with extract

$B$. cereus bacteria before (c) and after (d) contacted with extract

$P$. aeruginosa bacteria before (e) and after (f) contacted with extract

Figure 10. The Results of SEM Analysis on E. coli, B. cereus, and P. aeruginosa before and after contacted with Ethyl Acetate Extract of Red Melinjo Peel

\section{j. $\quad$ Leakage Analysis using AAS}

The detected ions on spectrophotometer instrument using AAS method indicates the leakage of microbial cell. Based on Table 3, it can be stated that ethyl acetate extract of red melinjo peel could damage the cell membrane and causing the leakage of E. coli, B. cereus, and P. aeruginosa.
Sodium, potassium, calcium, and magnesium are ions contained in bacteria [40]. Potassium ions located in the cytoplasm membrane as membrane transport [41]. Calcium ions serve as a messenger that brings the signal from the surface to the inner part of the cell [42]. Meanwhile, magnesium ions serve as membrane cell constituent [43]. 


\section{k. SEM Analysis}

Before exposure to ethyl acetate extract of red melinjo peel, the bacterial cell has a normal shape and soft surface (Figure 10 (a), (c), and (e)). However, after contacting with extract for 24 hours, the cells were damaged. The damages included shrinkage, cell swelling, cell surface tended to be rough, irregular shape (Figure 10 (b), (d), and (f)), and elongation $(10(d))$. The cell morphology damage is also supported by the AAS analysis on Table 3, that shows the cell leakage so calcium, magnesium, and potassium ions released from bacteria cell that already contacted with the extract.

$E$. coli and $P$. aeruginosa shrank and swelled after contacting with extract (Figure 10 (b) and (f)). However, $B$. cereus shrank, swelled, and elongated after contacted with the extract (Figure 10 (d)). The bacterial cell shrinkage is caused by antimicrobial compounds that enter due to the increase of cell membrane permeability. Phytochemical compounds contained in an extract that caused cell damage were alkaloids [44], saponin [45], phenolics [46], and flavonoids [47]. The bacterial cell shrinkage is caused by the differences in osmotic pressure, causing cytoplasm to come out, and leading to crenation (cell shrinkage). Meanwhile, changes of bacterial cell shape are caused by penetration of ethyl acetate extract of red melinjo peel and lead to cell swelling [4].

Table 3. The Results of AAS Analysis against E. coli, $B$. cereus, and $P$. aeruginosa after contacted with Selected Ethyl Acetate Extract of Red Melinjo Peel

\begin{tabular}{|l|c|c|c|}
\hline \multicolumn{1}{|c|}{ Microbes } & $\begin{array}{c}\text { Amount } \\
\text { of Ca }^{\mathbf{2}} \\
(\mathbf{m g} / \mathbf{L})\end{array}$ & $\begin{array}{c}\text { Amount of } \\
\mathbf{M g}^{\mathbf{2}} \\
(\mathbf{m g} / \mathbf{L})\end{array}$ & $\begin{array}{c}\text { Amount } \\
\text { of } \mathbf{K}^{+} \\
(\mathbf{m g} / \mathbf{L})\end{array}$ \\
\hline E. coli & 79 & 41.2 & 314 \\
\hline B. cereus & 84.2 & 33.3 & 348 \\
\hline P. aeruginosa & 82 & 31.3 & 327 \\
\hline
\end{tabular}

\section{Conclusions}

Results of the study showed that ethyl acetate extract of red melinjo peel could inhibit E. coli, B. cereus, and $P$. aeruginosa, but could not inhibit $R$. oligosporus. The average of inhibition zone diameter at $4,8,12$, and $16 \%$ concentrations are $10.74 \mathrm{~mm}, 11.70 \mathrm{~mm}$, and $11.27 \mathrm{~mm}$ respectively. The MIC values against $E$. coli, B. cereus, and $P$. aeruginosa are $0.69 \%, 0.50 \%$, and $0.67 \%$ respectively. While the MBC values are $2.76 \%, 2.00 \%$, and $2.68 \%$. The selected ethyl acetate extract of red melinjo peel was at $12 \%$ concentration that was used for the next analysis. Phytochemical compounds contained in the ethyl acetate extract of red melinjo peel was alkaloids, phenolics, flavonoids, saponin, and glycosides, that has antimicrobial properties.

The antibacterial activity of the selected ethyl acetate extract of red melinjo peel 1.47 times greater than 1000 ppm Colistin, while 0.74 times smaller than $100 \mathrm{ppm}$ Penicillin $G$ antibiotics. The ethyl acetate extract of red melinjo peel has greater antibacterial activity at $\mathrm{pH} 4$ than $\mathrm{pH}$ 7. Heating at $65^{\circ} \mathrm{C}$ would increase the antibacterial activity, while heating at 75,85 , and $95^{\circ} \mathrm{C}$ would damage the phytochemical compounds, causing the inhibition zone diameter to decrease. Addition of salt up to $5 \%$ and sugar up to $50 \%$ could increase the antibacterial activity of the ethyl acetate extract of the red melinjo peel.

The results of AAS analysis showed that E. coli, $B$. cereus, and $P$. aeruginosa leaked after contacted with ethyl acetate extract of red melinjo peel. Calcium, magnesium, and potassium ions were released from the bacterial cell membrane. As a result of contacting bacterial cells with the selected extract, there was shrinkage, swelling, elongation, and the cell surface became rough.

\section{SUGGESTIONS}

The suggestions that can be given for further study is to conduct phytochemical analysis quantitatively, to know the alkaloids, phenolics, flavonoids, saponins, and alkaloids content. Temperature and heating time treatment can be added in the extract stability test against heat treatment. In vivo testing of melinjo peel is necessary against experimental animals.

\section{ACKNOWLEDGMENT}

We thank the Rector of the University of Pelita Harapan (UPH), LPPM UPH and Ministry of Research, Technology and Education of the Republic Indonesia under Penelitan Unggulan Terapan Perguruan Tinggi cohort 2017 for their support and funding.

\section{REFERENCES}

[1] C. C. Barua, P. Haloi, and I. C. Barua, "Gnetum gnemon Linn.: a comprehensive review on its biological, pharmacological and pharmacognostical potentials," International Journal of Pharmacognosy and Phytochemical Research vol. 7(3), pp. 531-539, 2015.

[2] Badan Pusat Statistik, Statistik Tanaman Buahbuahan dan Sayuran Tahunan, Jakarta: Badan Pusat Statistik, 2015.

[3] A. J. N. Parhusip, and A. B. Sitanggang, "Antimicrobial activity of melinjo seed and peel extract (Gnetum gnemon) against selected pathogenic bacteria," Journal of Microbiology Indonesia vol. 5(3), pp. 103-112, 2011.

[4] J. Octavia, "Analisis kerusakan sel mikroba patogen akibat aktivtias antimikroba ekstrak biji dan kulit melinjo (Gnetum gnemon L.)," STP., Thesis, Universitas Pelita Harapan, Karawaci, 2010.

[5] U. Yanuhar, Mikroalga Laut Nannochloropsis oculata, Malang: UB Press, 2016.

[6] T. M. Siregar, M. Cornelia, Ermiziar, and Raskita, "Studi kandungan karotenoid, vitamin $\mathrm{C}$ dan aktivitas antioksidan kulit melinjo (Gnetum 
gnemon L.)," Prosiding Seminar Nasional PATPI, Jakarta, 2009, November 3-4, 2009.

[7] R. Gyawali, and S. A. Ibrahim, "Natural products as antimicrobial agents," Journal of Food Control vol. 46, pp. 412-429, 2014.

[8] L. Pratiwi, A. Fudholi, R. Martien, and S. Pramono, "Ekstrak etanol, ekstrak etil asetat, fraksi etil asetat, dan fraksi n-heksan kulit manggis (Garcinia mangostana L.) sebagai sumber zat bioaktif penangkal radikal bebas," Journal of Pharmaceutical Science and Clinical Research vol. 1, pp. 71-82, 2016.

[9] I. Fidrianny, K. R. Wirasutisna, and P. Amanda, "Senyawa antioksidan dari ekstrak etil asetat daun binahong (Anredera cordifolia (Ten.) Steenis) dari Babakan Ciparay, Bandung Selatan, Indonesia," Journal of Acta Pharmaceutica Indonesia vol. 38(1), pp. 26-30, 2013.

[10] E. Kato., Y. Tokunaga., and S. Fujio., "Stilbenoids isolated from the seeds of melinjo (Gnetum gnemon L.) and their biological activity," Journal of Agricultural and Food Chemistry vol. 57, pp. 2544-2549, 2009.

[11] Misna, and K. Diana, "Aktivitas antibakteri ekstrak kulit bawang merah (Allium cepa L.) terhadap bakteri Staphylococcus aureus," Journal of Pharmacy vol. 2(2), pp. 138-144, 2016.

[12] C. Dewi, R. Utami, and N. H. R. Parnanto., "Aktivitas antioksidan dan antimikroba ekstrak melinjo (Gnetum gnemon L.)," Journal of Agricultural Technology vol. 5(2), pp. 74-81, 2012.

[13] R. Nugrahani, Y. Andayani, and A. Hakim, "Skrining fitokimia dari ekstrak buah buncis (Phaseolus vulgaris L) dalam sediaan serbuk," Journal of Research in Science Education vol. 2(1), pp. 96-103, 2016.

[14] N. Tamilselvi, P. Krishnamoorthy, R. Dhamotharan, P. Arumugam, and E. Sagadevan, "Analysis of total phenols, total tannins and screening of phytocomponents in Indigofera aspalathoides (Shivanar Vembu) Vahl EX DC," Journal of Chemical and Pharmaceutical Research vol. 4(6), pp. 3259-3262, 2012.

[15] N. E. Syafitri, M. Bintang, and S. Falah, "Kandungan fitokimia, total fenol, dan total flavonoid ekstrak buah harendong (Melastoma affine D. Don)," Current Biochemistry Journal vol. 1(3), pp. 105-115, 2014

[16] S. N. Ergina, and I. D. Pursitasari, "Uji kualitatif senyawa metabolit sekunder pada daun palado (Agave angustifolia) yang diekstraksi dengan pelarut air dan etanol," Journal of Academic Chemistry vol. 4(3), pp. 165-172, 2014.

[17] A. P. Asmara, "Uji fitokimia senyawa metabolit sekunder dalam ekstrak metanol bunga turi merah
(Sesbania grandiflora L. Pers)," Alchemist Journal vol. 5(1), pp. 48-59, 2017.

[18] Depkes RI, Materi Medika Indonesia, vol. 5, Jakarta: Departemen Kesehatan Republik Indonesia, 1989.

[19] Ardiansyah, L. Nuraida, and N. Andarwulan, "Aktivitas antimikroba ekstrak daun beluntas (Plucea indica L.) dan stabilitas aktivitasnya pada berbagai konsentrasi garam dan tingkat $\mathrm{pH}$," Journal of Food Technology and Industry vol. 14 (2), pp. 90-97, 2003.

[20] Ardiansyah, "Kajian aktivitas antimikroba ekstrak daun beluntas (Plucea indica L.)," M.Si., Thesis, Institut Pertanian Bogor, Bogor, 2002.

[21] K. S. de L. Mota, F. de O. Pereira, W. A. de Oliveira, I. O. Lima, dan E. de O. Lima, "Antifungal activity of Thymus vulgaris L. essential oil and its constituent phytochemicals against Rhizopus oryzae: interaction with ergosterol," Molecules Journal vol. 17, pp. 14418 14433, 2012.

[22] D. Baurain, A. Wilmotte, and J. M. Frere, "Gramnegative bacteria: "inner" vs. "cytoplasmic" or "plasma membrane": a question of clarity rather than vocabulary," Journal of Microbial and Biochemical Technology vol. 8(4), pp. 325-326, 2016.

[23] A. Widyasanti, A. M. Prianti, and D. Rohdiana, "Aktivitas antibakteri Bacillus cereus dan Shigella dysenteriae ekstrak teh putih dalam variasi jenis pelarut," Indonesian Journal of Tea and Cinchona Research vol. 1(19), pp. 41-56, 2016.

[24] Y. H. Lai, and Y. Y. Lim, "Evaluation of antioxcidant activities of the methanolic extract of selected ferns in Malaysia," International Journal of Environmental Science and Development vol. 2(6), pp. 442-447, 2011.

[25] W. P. Rezende, L. L. Borges, D. L. Santos, N. M. Alves, and J. R. Paula, "Effect of environmental factors on phenolic compounds in leaves of Syzygium jambos (L.) Alston (Myrtaceae)," Journal of Modern Chemistry \& Applications vol. 3(2), 2015, from https://www.omicsonline.org/open-access/effectof-environmental-factors-on-phenoliccompounds-in-leaves-of-syzygium-jambos-1alston-myrtaceae-2329-6798-1000157.pdf. Accessed 2018, December 16.

[26] P. S. Widyawati, T. D. W Budianta, F. A. Kusuma, and E. L. Wijaya, "Difference of solvent polarity to phytochemical content and antioxidant activity of Pluchea indicia Less leaves extracts," International Journal of Pharmacognosy and Phytochemical Research vol. 6(4), pp. 850-855, 2014.

[27] J. M. Conly, and B. L. Johnston, "Colistin: the phoenix arises," Canadian Journal of Infectious 
Diseases and Medical Microbiology vol. 17(5), pp. 267-269, 2006.

[28] A.Dowling, J. O. Dwyer, and C. C. Adley, "Antibiotics: Mode of Action and Mechanisms of Resistance. Formatex Research Center," in Antimicrobial Research: Novel Bioknowledge and Educational Programs, ed. A. Mendez-Vilaz, pp. 536-545, Spanyol: Formatex Research Center, 2017.

[29] G. N. Cepeda, M. M. Lisangan, and I. Silamba, "Aktivitas antibakteri ekstrak kulit kayu akway (Drimys piperita Hook f.) terhadap Bakteri Patogen," Agritech Journal vol. 35(2), pp. 170$177,2015$.

[30] B. Ray, Fundamental Food Microbiology, $2^{\text {nd }}$ ed., New York: CRC Press, 2001.

[31] H. L. Alakomi, E. Skytta, M. Saarela, and T. Mattila-Sandholm, "Lactic acid permeabilizes Gram-negative bacteria by disrupting the outer membran," Journal of Applied Environmental Microbiology vol. 66, pp. 2001-2005, 2000.

[32] N. Jahan, Md. A. Islam, F. Alam, S. H. Gan, and Md. I. Khalil, "Prolonged heating of honey increases its antioxidant potential but decreases its antimicrobial activity," African Journal of Traditional, Complementary and Alternative Medicines vol. 12(4), pp. 134-144, 2015.

[33] K. Jeong-Youn, Y. C. Lee, and K. S. Kim, "Effect of heat treatments on the antimicrobial activities of garlic (Allium sativum)," Journal of Microbiology and Biotechnology vol. 12(2), pp. 331-335, 2002.

[34] S. Settharaksa, A. Jongjareonrak, P. Hmadhlu, W. Chansuwan, and S. Siripongvutikorn, "Flavonoid, phenolic contents and antioxidant properties of thai hot curry paste extract and its ingredients as affected of $\mathrm{pH}$, solvent types and high temperature," International Food Research Journal vol. 19(4), pp. 1581-1587, 2012.

[35] Amalia, R. D. Dwiyanti, and Haitami, "Daya hambat $\mathrm{NaCl}$ terhadap pertumbuhan Staphylococcus aureus," Medical Laboratory Technology Journal vol. 2(2), pp. 42-45, 2016.

[36] R. Naufalin, Kecombrang, Antimikroba dan Pemanfaatannya sebagai Pengawet Pangan, Purwokerto: UPT Percetakan Unsoed, 2017.

[37] R. Naufalin, and S. R. Herastuti. "Microcapsule application of kecombrang flower extract: effect of concentration, type of fraction, $\mathrm{pH}$ of medium and $\mathrm{NaCl}$ on microbiological properties of minced beef," Journal Animal Production vol. 15(1), pp. 8-14, 2013.

[38] R. Naufalin, and H. S. Rukmini, "Antibacterial activity of kecombrang flower extract (Nicolaia speciosa) microencapsulation with food additive materials formulation," International Symposium on Food and Agro-biodiversity 2017 102, 2017 , from

http://iopscience.iop.org/article/10.1088/17551315/102/1/012035/pdf , accessed 2018, December 8

[39] H. I. Hendritomo, "Perubahan mutu kecap skala industri rumah tangga selama tiga bulan,” Journal of Food Technology and Industry vol. 14(3), 2003.

[40] F. V. Sepulveda, and F. Benzanilla, Pumps, Transporters, and Ion Channels, New York: Kluwer Academic/ Plenum Publishers, 2005.

[41] C. A. Batt, and M. L. Tortorello, Encyclopedia of Food Microbiology, San Diego: Elsevier, Ltd., 2014.

[42] D. C. Dominiguez, "Calcium signalling in bacteria," Journal of Molecular Microbiology vol. 54(2), pp. 291-297, 2004.

[43] T. Brown, Gene Cloning and DNA Analysis: An Introduction, New Jersey: Blackwell Publishing, 2010.

[44] I. G. O. Darsana, I. N. K. Besung, dan H. Mahatmi, "Potensi daun binahong (Anredera cordifolia (Tenore) steenis) dalam menghambat pertumbuhan bakteri Escherichia coli secara in vitro," Indonesia Medicus Veterinus vol. 1(3), pp. 337-351, 2012.

[45] J. B. Harborne, Metode Fitokimia, $2^{\text {nd }}$ ed., Bandung: ITB, 2006

[46] C. D. Char, S. N. Guerrero, and S. M. Alzamora, "Mild thermal process combined with vanillin plus citral to help shorten the inactivation time for Listeria innocua in orange juice," Journal of Food and Bioprocess Technology vol. 3, pp. 752-761, 2010.

[47] M. C. Nuria, A. Faizatun, and Sumantri, "Uji aktivitas antibakteri ekstrak etanol daun jarak pagar (Jatropha Curcas L) terhadap bakteri Staphylococcus aureus ATCC 25923, Escherichia coli ATCC 25922, dan Salmonella typhi ATCC 1408," Mediagro vol. 5(2), pp. 26-37, 2009. 